\title{
REALIZM STRUKTURALNY A PROBLEM REPREZENTACJI W NAUCE W KONTEKŚCIE SPORU O REALIZM NAUKOWY
}

\begin{abstract}
Streszczenie. Przedmiotem artykułu jest ukazanie realizmu strukturalnego jako stanowiska realistycznego w dyskusji prowadzonej wokół realizmu naukowego - jego wybranych zalet i słabości. Realizm strukturalny jest odpowiedzią na wyzwanie, jakie realizmowi naukowemu stawiają historyczne fakty zmiany teorii w nauce. Nawiązuje on do semantycznego ujęcia teorii naukowych i wypracowanego w tym podejściu aparatu pojęciowego. Zgodnie z realizmem strukturalnym to, co zostaje zachowane z dojrzałych teorii naukowych po zmianie teorii, to ich sformułowania matematyczne, będące abstrakcyjnymi modelami teorii. Są one aproksymacyjnie prawdziwe, gdyż reprezentują realne struktury rzeczywistości w sposób wolny od ontologicznej interpretacji, narzuconej przez język teorii. Realizm strukturalny i nawiązujący do niego semirealizm, który rozszerza niezmienniczość dojrzałych teorii na własności detekcyjne obiektów fizycznych, bronią tezy realizmu naukowego w kwestii aproksymacyjnej prawdziwości teorii naukowych, interpretując realistycznie zmiany teorii naukowych. Pozostawiają jednak na boku istotny dla realizmu problem reprezentowania rzeczywistości w teoriach naukowych. Oba wspomniane stanowiska, nawiązując do modelowego ujęcia teorii naukowych, przyjmują, że reprezentacja jest izomorfizmem struktur matematycznego modelu teorii i rzeczywistości. Takie rozumienie reprezentacji jest zbyt wąskie, nie uwzględnia, że struktura zjawisk nie jest jednoznacznie określona. Strukturę tę dla teorii zastępuje matematyczny model danych, który odzwierciedla zjawiska przedstawione jako związki własności określonych przez teorię. Realistyczna interpretacja modelu danych stanowi dla realizmu strukturalnego konieczne uzupełnienie, aby spełniał on naczelną tezę realizmu, głoszącą, że nauka poznaje świat taki, jaki jest niezależnie od teorii. Stanowi to podstawę, aby broniona w realizmie strukturalnym aproksymacyjna prawdziwość teorii naukowych miała ugruntowane uzasadnienie. Wskazanie potrzeby rozszerzenia realizmu strukturalnego i semirealizmu o odpowiednią dla nich koncepcję reprezentacji jest tezą tej pracy. W artykule zostały przedstawione podstawowe elementy współczesnej dyskusji wokół realizmu naukowego oraz stanowiska realizmu strukturalnego i semirealizmu jako uzgodnienie realizmu naukowego z faktem radykalnej zmiany teorii. Następnie zostały ukazane konsekwencje, jakie dla realizmu strukturalnego wynikają z semantycznego (modelowego) ujęcia teorii naukowych i związanego z tym pojęcia reprezentacji jako izomorfizmu struktur. Ostatni fragment został poświęcony wskazaniu, że aby spełnić postulaty realizmu naukowego zarówno realizm strukturalny, jak i semirealizm
\end{abstract}


powinny być uzupełnione o interpretację reprezentacji rzeczywistości w modelu danych w duchu realizmu naukowego.

Słowa kluczowe: realizm naukowy; realizm strukturalny; semirealizm; reprezentacja rzeczywistości w nauce; model teorii; dane modelu, struktura teorii naukowej

1. Wstęp. 2. Główne tezy realizmu naukowego i ich ewolucja w dyskusji z antyrealizmem. 3. Realizm strukturalny jako odpowiedź realizmu na fakt radykalnej zmiany teorii. 4. Konsekwencje semantycznego ujęcia teorii naukowych dla realizmu naukowego. 5. Modele danych i reprezentacja rzeczywistości w teoriach naukowych. 6. Zakończenie.

\section{WSTĘP}

Współczesna dyskusja wokół realizmu naukowego koncentruje się w dużej mierze wokół osi wyznaczonej przez dwa główne argumenty opozycyjnych stanowisk: argument $\mathrm{z}$ sukcesu nauki na rzecz realizmu naukowego i kontrargument ze zmiany teorii naukowych. Próby odpowiedzi na wyzwanie, jakie postawił przed realizmem naukowym fakt radykalnej zmiany teorii, skutkowały znacznym osłabieniem tez realizmu naukowego, jak i pewnym ukierunkowaniem dyskusji. Szczególny nacisk położono na te treści realizmu, które odnoszą się do prawdziwości (aproksymacyjnej) teorii naukowych. Dominujące odpowiedzi realizmu na argument radykalnej zmiany teorii to realizm strukturalny i semirealizm, które odwołują się do stałości struktur teoretycznych przy zmianie teorii. Rozumienie teorii naukowych w obu propozycjach mieści się w ramach semantycznego ujęcia utożsamiającego (bardziej lub mniej) teorie naukowe $\mathrm{z}$ rodzinami modeli. Ujęcie to niesie pewne konsekwencje dla realizmu strukturalnego, które stanowią poważną trudność dla stanowiska realistycznego. Ze względu na podobieństwo generowanych problemów przez wspomniane stanowiska główne miejsce w poniższej dyskusji zajmuje realizm strukturalny.

Realizm strukturalny uznaje, że niezinterpretowany formalizm matematyczny teorii reprezentuje realne struktury rzeczywistości, przez co, jako niezależny od języka teorii, pozostaje niezmieniony 
w wyniku zmiany teorii. Semirealizm rozciąga ową niezmienniczość na własności detekcyjne, których własności matematyczne upodabniają je do modelu danych. Sukcesem obu teorii jest wykazanie pewnej kumulatywności wiedzy wobec zmiany teorii naukowych, dokonuje się to jednak zarówno kosztem znacznego osłabienia realizmu naukowego, jak i pozostawieniem nieco z boku jego głównej tezy, że nauka poznaje świat niezależny od teoretycznych założeń.

Ważnym problemem, który realizm strukturalny musi rozwiązać, jest kwestia reprezentacji świata w matematycznych strukturach równań, stanowiących modele teorii. Celem niniejszego artykułu jest pokazanie konieczności poszerzenia przyjmowanej w tym stanowisku koncepcji reprezentacji jako izomorfizmu struktur, która to koncepcja jest za wąska dla realistycznego wyjaśnienia związku teorii i rzeczywistości. Poszerzenie realistycznej interpretacji stosunku modeli strukturalnych, jakimi są równania matematyczne teorii, do realnych zjawisk, jest przedmiotem tej pracy. Pozwoli to odsłonić pewne trudności realizmu strukturalnego, które powinny być wyjaśnione z perspektywy realizmu naukowego.

\section{GŁÓWNE TEZY REALIZMU NAUKOWEGO I ICH EWOLUCJA W DYSKUSJI Z ANTYREALIZMEM}

Realizm naukowy jest stanowiskiem, które w różnych formach wyraża ideę, że nauka bada i opisuje świat, jaki istnieje niezależnie od ludzkiego poznania, i że rezultatem tego poznania bywa prawdziwa lub aproksymacyjnie prawdziwa wiedza na temat badanych zjawisk. Dyskusja wokół realizmu naukowego dotyczy samej istoty nauki, a w szczególności statusu poznawczego teorii naukowych i ich odniesienia do rzeczywistości. Poszczególni autorzy różnią się co do szczegółowego sformułowania stanowiska realizmu naukowego, jednak zawsze pozostaje teza, że realizm naukowy uznaje wyniki nauk empirycznych za wiedzę o świecie, która w znacznym zakresie jest prawdziwa w sensie klasycznej teorii prawdy, a terminy nauki 
w zasadzie odnoszą się do realnych przedmiotów, zarówno obserwowalnych, jak i nieobserwowalnych. W miarę rozwoju dyskusji i pod wpływem różnych argumentów to stanowisko jest uszczegóławiane i doprecyzowywane na różne sposoby. Niektóre sformułowania realizmu kładą nacisk na tezę, że teorie naukowe są prawdziwe lub w przybliżeniu prawdziwe (realizm odnośnie do teorii naukowych). Inne akcentują tezę, że przedmioty i zjawiska, postulowane przez dojrzałe teorie naukowe istnieją realnie, tzn. niezależnie od naszego poznania (realizm w kwestii przedmiotów teoretycznych) ${ }^{42}$.

Ogólnie mówiąc, stanowisko realistyczne wiąże się z przyjęciem jakiegoś typu rzeczy lub zjawisk za realne. Jest przedmiotem dyskusji, co dokładnie realizm naukowy uznaje za realne. Jednak to, co realne (np. obiekty, własności, struktury, relacje) jest ujmowane poznawczo przez dojrzałe teorie i modele zjawisk niezależnie od założeń teoretycznych.

U początku obecnie toczonej dyskusji wokół realizmu naukowego leży sformułowanie realizmu naukowego w wersji tzw. realizmu konwergentnego, którego ewolucję zapoczątkowała znana krytyka Larry'ego Laudana. Doprowadziła ona do doprecyzowania i osłabienia tez realizmu, i ostatecznie do pojawienia się nowych stanowisk realistycznych, takich jak realizm strukturalny i semirealizm. Stanowisko realizmu naukowego (konwergentnego) jest według Richarda Boyda wyrażone w układzie czterech tez: (1) terminy teoretyczne dojrzałych teorii powinny być interpretowane realistycznie, to znaczy, że postulowane przez teorie nieobserwowalne obiekty realnie istnieją; (2) teorie naukowe realistycznie interpretowane są potwierdzalne i często potwierdzone zwykłymi metodami empirycznymi jako prawdziwe lub w przybliżeniu prawdziwe; (3) postęp dojrzałej nauki przebiega w kierunku coraz bardziej prawdziwej wiedzy na temat obserwowalnych i nieobserwowalnych zjawisk; (4) rzeczywistość

42 Por. A. Chakravartty, A Metaphysics for Scientific Realism: Knowing the Unobservable, Cambridge 2007. 
opisywana przez teorie naukowe jest w większości niezależna od naszego umysłu i przyjętych założeń teoretycznych ${ }^{43}$.

Zdaniem Stathisa Psillosa realizm pociąga za sobą w konsekwencji: (1) tezę metafizyczną, że badany przez naukę świat istnieje niezależnie od ludzkiego umysłu i ma określoną niezależną od naszego umysłu strukturę; (2) tezę epistemologiczną, że dojrzałe i odnoszące sukces predykcyjny teorie są prawdziwe lub aproksymacyjnie prawdziwe; oraz (3) stanowisko semantyczne, że teorie naukowe powinny być interpretowane dosłownie, co znaczy, że terminy nieobserwowalnych bytów (obiektów, zdarzeń, procesów, własności itd.), postulowanych przez teorie, mają realne odniesienia ${ }^{44}$.

Krytyka realizmu z pozycji antyrealistycznych zwrócona jest często przeciwko którejś z wymienionych tez, np. z pozycji empiryzmu kwestionowana jest teza pierwsza (o realnym istnieniu nieobserwowalnych przedmiotów postulowanych przez teorię) i teza druga (w której odrzucana jest prawdziwość teorii na rzecz ich empirycznej adekwatności). Konstruktywiści natomiast negują tezę czwartą (o możliwości poznania świata niezależnego od naszych założeń teoretycznych).

Jednym $\mathrm{z}$ najbardziej znaczących argumentów na rzecz realizmu naukowego jest sformułowany przez $\mathrm{H}$. Putnama argument $\mathrm{z}$ sukcesu nauki, zwany też argumentem z braku cudów (NMA). Putnam stwierdził, że „realizm jest jedynym stanowiskiem filozoficznym, które nie czyni sukcesu nauki cudem" 45 . Zgodnie z tym argumentem najlepszym wyjaśnieniem sukcesu współczesnych teorii (takich jak np. teoria względności czy teoria kwantowa) jest uznanie, że teorie

43 R. Boyd, On the Current Status of the Issue of Scientific Realism, Erkenntnis 19(1983)1, 45. Dojrzałe teorie w tym kontekście oznaczają teorie empirycznie dobrze potwierdzone i dostarczające skutecznych nowatorskich przewidywań odnośnie do nowej kategorii zjawisk.

44 S. Psillos, Scientific realism and metaphisics, Ratio (new series) 18(2005)4, 385-386

$45 \mathrm{H}$. Putnam, What is Mathematical Truth?, w: Tenże, Mathematics, Matter and Method, Collected Papers, Vol. 2, Cambridge 1975, 73. 
te są prawdziwe lub aproksymacyjnie prawdziwe. Taka intuicyjna i ogólna idea od samego początku budziła wiele wątpliwości i była podatna na krytykę za brak ścisłości i precyzji. Wymagała też bardziej formalnego zapisu ${ }^{46}$.

Najbardziej znaczącą krytykę tego argumentu przedstawił Larry Laudan w 1981 roku. Odwołując się do faktów z historii nauki, pokazał, że było wiele teorii, które - pomimo iż odniosły sukces empiryczny - okazywały się fałszywe z perspektywy rozwoju nauki, a postulowane przez nie nieobserwowalne obiekty (jak np. flogiston czy eter) okazywały się nie istnieć w świetle kolejnych teorii ${ }^{47}$. Sukces teorii nie przesądza ani o jej prawdziwości, ani o istnieniu postulowanych przez nią obiektów teoretycznych. Zdaniem Laudana wskazane przez niego fakty podważają argument $z$ sukcesu nauki, a przez to także realizm naukowy.

Krytyka Laudana wplata się w ogólną ideę mocnego kontrargumentu przeciwko realizmowi, jakim jest pesymistyczna indukcja (PI). Argument PI odwołuje się do wnioskowania, że jeśli przeszłe teorie, które w swoim czasie odnosiły sukces, okazywały się wraz z rozwojem nauki fałszywe, to nawet nasze najlepsze współczesne teorie odnoszące sukces mogą okazać się w przyszłości fałszywe. Sukces teorii, nawet sukces predykcyjny, w kontekście radykalnej zmiany teorii nie jest argumentem na rzecz jej prawdziwości. Ten kontrargument stał się dla realizmu poważnym wyzwaniem i wpłynął

46 Argument Putnama został sformułowany jako wnioskowanie do najlepszego wyjaśnienia. Por. np. A. Grobler, Prawda a względność, Kraków 2000, 110. Dyskusja wokół Bayesianskiego sformułowania tego argumentu dotyczy jego formalnych aspektów. Np. C. Howson przedstawił i rozwinął bayesowską rekonstrukcję NMA, wykazując, że jest to argument wewnętrznie sprzeczny. Por. C. Howson, Exhuming the No Miracles Argument, Analysis 73(2013)2, 205-211. Inni autorzy uważają jednak, że bayesowskie sformułowanie nie jest odpowiednie dla NMA. Por. np. S. Psillos, Knowing the Structure of Nature, New York 2009; J. Worrall, Miracles and Models: Why Reports of the Death of Structural Realism May Be Exaggerated, Royal Institute of Philosophy. Supplement 61(2007)10, 125-154.

47 L. Laudan, Obalenie realizmu konwergentnego, tłum. z ang. M. Kotowski, w: Spór o realizm naukowy. Mała antologia, red. M. Kotowski, Wrocław 2018, 35-47. 
znacząco na ewolucję stanowiska realistycznego oraz na wybór strategii jego obrony.

W wyniku PI doprecyzowano kryteria, jakie mają spełniać teorie, które bierze się pod uwagę $\mathrm{w}$ dyskusji nad realizmem naukowym. Według realistów, takich jak John Worrall i Stathis Psillos, są to tylko tzw. „dojrzałe” teorie naukowe, jak np. w fizyce teoria względności czy teoria kwantowa. Teorie te obok sukcesu predykcyjnego charakteryzuje dodatkowo stabilność w czasie i ugruntowanie w odniesieniu do innych dobrze potwierdzonych (zgodnie $\mathrm{z}$ metodologią danej dziedziny) teorii. Ograniczenia te nie eliminują jednak niektórych teorii, które choć spełniały warunki sukcesu dojrzałych teorii, to zostały odrzucone.

Obok argumentu z sukcesu nauki Laudan poddał krytyce główne tezy realizmu. Poza zanegowaniem tezy, że dojrzałe teorie naukowe są na ogół aproksymacyjnie prawdziwe, a teorie nowsze w danej dziedzinie są bliższe prawdy niż teorie starsze, oraz tezy, że obserwacyjne oraz teoretyczne pojęcia, występujące w teoriach nauk dojrzałych, posiadają odniesienie przedmiotowe, podważa też odpowiedzi realizmu naukowego na problem niewspółmierności następujących po sobie teorii, według których wcześniejsze teorie będą „przypadkami granicznymi” późniejszych i jako takie będą „zachowywać” teoretyczne obiekty i relacje teorii wcześniejszych. Dodatkowo neguje również twierdzenie, że „nowe teorie wyjaśniają i powinny wyjaśniać, dlaczego ich poprzedniczki odniosły sukces o tyle, o ile go odniosły" 48 .

Krytyka Laudana kieruje obronę realizmu w stronę uzgodnienia go $\mathrm{z}$ zachodzącymi w historii nauki radykalnymi zmianami teorii. Zachowując argument $\mathrm{z}$ sukcesu nauki, należy wykazać jego przynajmniej częściowy związek z prawdziwością teorii. Ta linia dyskusji koncentruje się wokół zagadnienia prawdziwości (aproksymacyjnej prawdziwości) teorii naukowych i realności ich ontologii.

48 Por. tamże, 31. 
Zagadnienie stosunku teorii do rzeczywistości jest na tym etapie dyskusji ograniczone do zagadnienia prawdy.

\section{REALIZM STRUKTURALNY JAKO ODPOWIEDŹ REALIZMU NA FAKT RADYKALNEJ ZMIANY TEORII}

Uzgodnienie aproksymacyjnej prawdziwości teorii i jej sukcesu z historycznymi faktami zmiany teorii jest głównym wyzwaniem dla obrońców stanowiska realistycznego. J. Worral zaproponował w 1988 roku realizm strukturalny jako odpowiedź na to wyzwanie ${ }^{49}$. Przyjmuje on, że nie jest możliwa obrona prawdziwości całych odnoszących sukces teorii, które zostały zastąpione nowszymi, można jednak wskazać elementy/fragmenty tych teorii, bezpośrednio związane $\mathrm{z}$ ich sukcesem, których aproksymacyjnej prawdziwości można bronić. Elementy te stanowią kumulatywny element wiedzy, tzn. są zachowane w kolejnej i następnych teoriach, i z tego powodu można je interpretować realistycznie, gdyż argument PI, że zostały odrzucone przez następne teorie, nie odnosi się do nich. Można więc uznać je zgodnie $\mathrm{z}$ argumentem $\mathrm{z}$ sukcesu nauki za aproksymacyjnie prawdziwe ${ }^{50}$.

Bas van Frassen utrzymuje, że kumulatywna jest tylko treść empiryczna teorii i jej sukces predykcyjny, podczas gdy treść teoretyczna

49 Zob. J. Worrall, Realizm strukturalny. To co najlepsze z dwóch światów, tłum. z ang. M. Kotowski, w: Spór o realizm naukowy, dz. cyt., 145-175.

50 Przyjmowana często strategia obrony realizmu, którą stosuje też J. Worrall nosi miano divide et impera i oznacza, że odrzucone teorie, choć nie są w całości aproksymacyjnie prawdziwe, to zawierają pewne elementy, które można wyodrębnić jako bezpośrednio odpowiedzialne za sukces predykcyjny teorii, i które można w świetle nowszych teorii uznać za aproksymacyjnie prawdziwe. Te fragmenty i tylko one zostają w jakiejś formie zachowane w teoriach następnych jako kumulatywny składnik wiedzy o zjawiskach. Por. np. T.D. Lyons, Scientific Realism and the Stratagema de Divide et Impera, The British Journal for the Philosophy of Science 57(2006)3, 537-560; S. Psillos, Scientific Realism: How Science Tracks Truth, London 1999, 108. 
teorii nie jest kumulatywna ${ }^{51}$. Worrall natomiast twierdzi, że nie tylko treść empiryczna teorii $\mathrm{T} 1$ jest zachowana w nowej teorii T2, ale $\mathrm{i}$ istotna treść teoretyczna, którą stanowią równania matematyczne. Nawiązując do pracy Henry'ego Poincarego, według którego matematyczne równania dojrzałych teorii naukowych odzwierciedlają realne relacje pomiędzy własnościami nieobserwowalnych składników rzeczywistości52 ${ }^{52}$ Worrall formułuje realizm strukturalny, który głosi, że prawdziwą (i kumulatywną) część teorii stanowią niezinterpretowane równania matematyczne teorii. Równania te odzwierciedlają realne nieobserwowalne struktury przyczynowe rzeczywistości. Zmiana teorii nie podważa samych struktur przyczynowych ani ich modeli matematycznych, choć może podważyć ontologię teorii. Obrazuje to na przypadku przejścia, jakie dokonało się w optyce pomiędzy teorią światła Fresnela (eterową) i teorią elektromagnetyczną Maxwella. Teoria Fresnela odniosła sukces predykcyjny, pomimo że przyjmowała istnienie eteru, co zostało $\mathrm{z}$ czasem zanegowane.

Worrall wskazuje jednak, że matematyczne równania sformułowane przez Fresnela zostały wyprowadzone z teorii Maxwella w tej samej formie matematycznej, podczas gdy ich interpretacja ontologiczna uległa całkowitej zmianie. Worrall twierdzi, że formalizm matematyczny pozwala na prawdziwe przewidywanie zjawisk, gdyż odzwierciedla realne, nieobserwowalne struktury rzeczywistości. Dlatego pozostaje niezmieniony przy przejściu od jednej dojrzałej teorii do drugiej, pomimo, że jego interpretacja ulega znaczącej zmianie. Jeśli zatem ograniczymy się do poziomu równań matematycznych, to na poziomie formalnym zachodzi zgodność pomiędzy teorią Fresnela i teorią Maxwella ${ }^{53}$.

Według Worralla o ciągłości równań można mówić także w przypadku, gdy równania teorii wcześniejszej są granicznymi przypadkami

51 Por. B. van Frassen, The Scientific Image, Oxford 1980, 40.

52 Por. H. Poincaré, Science and Hypothesis, New York 1905.

53 Por. J. Worrall, Realizm strukturalny..., dz. cyt., 169. 
odpowiednich równań nowszej teorii, jak np. w przypadku równań teorii Newtona i teorii relatywistycznej Einsteina. Ani nowe teorie, ani też ich równania nie są prostym rozszerzeniem starych, jak pokazuje Aniajan Chakravartty. Zazwyczaj oba układy równań są różne, mogą być nawet ze sobą sprzeczne, jednak równania nowszej teorii przyjmują postać równań starej, jeśli określona wielkość nowej teorii przyjmuje graniczną wartość ${ }^{4}$. Worrall uznaje, że graniczna zbieżność jest istotnym rodzajem kumulatywności i odpowiada tezie realizmu naukowego, że sukces predykcyjny dojrzałych teorii nie pozostaje bez związku z ich prawdziwością.

Konsekwencją realizmu strukturalnego jest to, że jedyna prawdziwa (aproksymacyjnie prawdziwa) wiedza naukowa o rzeczywistości ogranicza się tylko do formalizmu matematycznego. Według realizmu strukturalnego teorie naukowe nie mówią niczego wiążącego o naturze obiektów, ukrytych za tą strukturą. Natura i własności nieobserwowanych obiektów pozostają nieznane. Jest to jedno z podstawowych ograniczeń realizmu strukturalnego, które jest konsekwencją semantycznego (strukturalistycznego) rozumienia teorii naukowych, które Worrall podziela. To ograniczenie wiedzy jedynie do abstrakcyjnych struktur jest w zakresie realizmu przekroczone $\mathrm{w}$ ramach zaproponowanego przez Chakravartiego semirealizmu.

Chakravartty stawia tezę, że realizm strukturalny pociąga za sobą konsekwencje odnośnie do istnienia i własności obiektów teoretycznych (także nieobserwowalnych). Występowanie relacji wskazuje, że jakieś argumenty tworzą te relacje. Wykazuje on, że „wiedza o strukturach implikuje wiedzę zarówno o istnieniu bytów spełniających te struktury, jak i o ich niektórych właściwościach detekcyjnych" 55 . Nieobserwowalne obiekty ujawniają się przez ich przyczynowe własności.

54 Por. A. Chakravartty, Semirealizm, Studies in History and Philosophy of Science, 29(1998)3, 399.

55 Tamże. 
Dla sformułowania swojego stanowiska wprowadza rozróżnienie pojęciowe pomiędzy własnościami detekcyjnymi i pomocniczymi. Właściwości detekcyjne leżą u podstaw wykrywanych prawidłowości przyczynowych. To one są bezpośrednio związane z wykrywanymi prawidłowościami i koniecznie uwzględniane w interpretacji wzorów matematycznych. Natomiast własności pomocnicze odgrywają rolę heurystyczną w teoretycznym wyjaśnianiu zjawisk i nie są konieczne ze względu na odkrywane prawidłowości. Mogą one zarówno być odrzucone w przyszłych teoriach, jak i utrzymane, stając się, np. wraz z rozwojem technik detekcyjnych, własnościami detekcyjnymi. Wprowadza także kolejne rozróżnienie na struktury formalne i przyczynowe teorii empirycznej. Zwraca uwagę, że teorie fizyczne bazują na relacjach pomiędzy własnościami przyczynowymi obiektów fizycznych i skutkami, jakie wywołują na przyrządy pomiarowe. Występowanie relacji (przyczynowych) każe wnosić, że tworzą je jakieś obiekty, posiadające odpowiednie własności do ich utworzenia. Własności detekcyjne ujmowane $\mathrm{w}$ teorii ujawniają przyczynowe relacje, konstytuujące przyczynową strukturę rzeczywistości. Te własności, a właściwie wyłoniona przez nie struktura, są odzwierciedlane w równaniach matematycznych i powinny być uważane jako zachowywane w wyniku zmiany teorii. Według Chakravarttiego, wiedza strukturalna pociąga za sobą wiedzę o istnieniu obiektów tworzących tę strukturę oraz o ich własnościach detekcyjnych.

Odpowiedzią realizmu strukturalnego na problem prawdziwości teorii naukowych jest forma strukturalizmu, według którego struktury modeli matematycznych (niezinterpretowanych równań) reprezentują realne, choć niepoznawalne co do swej natury, struktury rzeczywistości. Izomorfizm tych struktur gwarantuje prawdziwość (zgodność z rzeczywistością) teorii, rozumianych jako abstrakcyjne modele rzeczywistości, pozbawione interpretacji ontologicznej. Realizm strukturalny jest rozwijany w dwu wersjach. Jedną jest epistemologiczny realizm strukturalny, który utrzymuje, że możemy poznać tylko same struktury relacyjne rzeczywistości, ale własności 
nieobserwowalnych obiektów, determinujących te struktury, pozostają niepoznawalne. Drugą wersją jest ontologiczny realizm strukturalny, zgodnie z którym realny jest jedynie strukturalny obraz rzeczywistości, natomiast obiekty pełnią w nauce tylko heurystyczną rolę. To, co realnie istnieje, to jedynie struktury. Stanowi to zawężenie i osłabienie realizmu ${ }^{56}$.

Zarówno realizm strukturalny, jak i semirealizm narażone są na znane trudności, często przytaczane w dyskusjach, które tu zostaną pominięte. Dalsze rozważania będą się skupiały na kwestii, która leży u podstaw całej dyskusji o realizmie, zarówno dyskusji na temat prawdziwości teorii naukowych, jak i realności obiektów teoretycznych. Problem ten dotyczy relacji teorii naukowej do rzeczywistości i jest to problem reprezentowania świata w nauce.

Van Frassen stawia pytania, skierowane zarówno do realizmu, jak i semirealizmu. Jak matematyczne struktury reprezentują fizyczną rzeczywistość? W jakim sensie konkretne fizyczne systemy są izomorficzne $z$ abstrakcyjnymi matematycznymi modelami? Co czyni system równań odpowiednią reprezentacją zjawisk ${ }^{57}$ ? Próba odpowiedzi na te pytania stanowi nie mniejsze wyzwanie dla realizmu naukowego niż zagadnienie zmiany teorii naukowych.

\section{KONSEKWENCJE SEMANTYCZNEGO UJĘCIA TEORII NAUKOWYCH DLA REALIZMU STRUKTURALNEGO}

Realizm strukturalny jest znaczącą odpowiedzią realizmu na problem zmiany teorii naukowych, jednak rodzi też poważne trudności, które zdaniem van Frassena są związane z podstawowym twierdzeniem tego stanowiska - tezą, że nauka reprezentuje zjawiska empiryczne,

56 Por. M. Kotowski O rozwoju realizmu naukowego jako selektywnego sceptycyzmu, Filozofia Nauki 22(2014)3, 105-123.

57 B. van Frassen, Representation: The problem for Structuralism, Philosophy of Science 73(2006)5, 539. 
których strukturę (pozbawioną wymiaru ontologicznego) odzwierciedla matematyczna struktura modelu teoretycznego. Realizm strukturalny przyjmuje semantyczne (strukturalno-modelowe) ujęcie teorii naukowych i podziela wszystkie jego trudności w wyjaśnieniu tego, czy w nauce poznajemy świat taki, jaki jest, niezależnie od teoretycznych założen. Zgodnie z tym ujęciem teorie są równoważne rodzinie modeli, będących abstrakcyjnymi strukturami, w których spełnione są aksjomaty teorii. W wypadku teorii empirycznych matematyczne modele reprezentują zjawiska empiryczne. Struktura jest w tym kontekście rozumiana na wzór struktury matematycznej, a najprostszą strukturę stanowi zbiór abstrakcyjnych obiektów i relacji, zachodzących pomiędzy nimi ${ }^{58}$. Zgodnie ze strukturalnym podejściem modele matematyczne są strukturami i reprezentują systemy empiryczne, których struktury są izomorficzne z tymi z modelami ${ }^{59}$. Modele w tym rozumieniu są czystymi strukturami abstrakcyjnych obiektów i relacji między nimi. Model matematyczny teorii będę dalej dla prostoty określać modelem teorii. Teoria naukowa dostarcza rodzinę modeli do reprezentowania zjawisk, ale przedstawia zjawiska jako fragmenty prostszej struktury - świata, jaki jest według teorii. Te modele są bytami matematycznymi, więc jedyne co posiadają to struktura, a to, co mogą reprezentować, to także tylko struktura. Czy zatem modele mogą reprezentować świat zjawisk prawdziwie lub fałszywie?

Zdaniem Chakravartiego podejście strukturalno-modelowe nie stanowi dobrego wsparcia dla realizmu naukowego ${ }^{60}$. Jeśli używane $\mathrm{w}$ nauce modele są matematycznymi strukturami, to teorie naukowe

58 Por. F. Suppe, The Semantic Conception of Theories and Scientific Realism, Chicago 1989; R. Giere, How Models Are Used to Represent Reality. Philosophy of Science 71(2004)5, 747; Tenże, Explaining Science: A Cognitive Approach, Chicago 1988, 270.

59 Por. N. da Costa, S. French, The Model-Theoretic Approach to the philosophy of Science, Philosophy of Science 57(1990)2, 249.

60 A. Chakravartty, The Semantic or Model Theoretic View of Theories and Scientific Realism, Synthese 127(2001)3, 325-345. 
odzwierciedlają jedynie abstrakcyjne struktury rzeczywistości, nie mówią natomiast nic na temat natury obiektów, tworzących te struktury. Struktury abstrakcyjne są rozróżnialne tylko z dokładnością do izomorfizmu. Izomorfizm struktur zatraca przedmiot reprezentacji (to, co model reprezentuje), np. zależność liniowa tak samo reprezentuje struktury złożone $z$ różnych obiektów ${ }^{61}$. Dla izomorfizmu jest ważna jedynie liczebność obiektów i relacje miedzy nimi, rozumiane ekstensjonalnie. Modele są natomiast reprezentacjami jakiegoś konkretnego systemu lub zjawiska, np. model atomu wodoru reprezentuje atom wodoru i nic innego, a matematyczny model wzrostu populacji bakterii nie reprezentuje rozpadu promieniotwórczego, choć ich modele matematyczne są izomorficzne, opisane tą samą funkcją eksponencjalną.

Według Worralla taka niezależność modelu od ontologii teorii jest zaletą tego ujęcia, gdyż pozwala na zachowanie modelu matematycznego teorii w obliczu zmiany teorii. Jak głosi realizm strukturalny, w strukturach matematycznych odzwierciedlana jest abstrakcyjna struktura przyczynowa zjawisk, dlatego wiedza o strukturach, zawarta w matematycznym sformułowaniu teorii, jest prawdziwą lub aproksymacyjnie prawdziwą wiedzą o rzeczywistości, choć wiedzą bardzo ograniczoną. To ograniczenie jest ceną płaconą za prawdziwość (aproksymacyjną prawdziwość) wiedzy naukowej. Wiedza o abstrakcyjnej strukturze zjawisk, jako aproksymacyjnie prawdziwa, jest kumulatywna i zachowuje się przy zmianie teorii. Van Frassen podważa jednak argument o kumulatywności wiedzy teoretycznej na temat rzeczywistości oraz tezę o jej aproksymacyjnej prawdziwości. Jego zdaniem kumulatywna jest jedynie wiedza empiryczna o zjawiskach, prawdziwość natomiast może być rozumiana tylko w sensie empirycznej adekwatności.

61 R. Frigg, Scientific Representation and the Semantic View of Theories, Theoria 21(2006)1, 54 
Jako wyzwanie dla realizmu strukturalnego, a także dla semirealizmu, van Frassen stawia pytanie: jak struktury matematyczne mogą reprezentować fizyczną rzeczywistość? Jego zdaniem realista strukturalny musi podzielać pogląd Reichenbacha na temat wzajemnej koordynacji struktur matematycznych i struktury rzeczywistości fizycznej ${ }^{62}$. Postulowanie takiej koordynacji wynika z przekonania, że struktury matematyczne odwzorowują właściwości zjawisk. Reichenbach zakłada niejawnie, że rzeczywistość posiada obiektywną, niezależną od teorii strukturę, którą można przyporządkować strukturze abstrakcyjnej bez odwoływania się do jakiegokolwiek języka teorii. Założenie to nie jest oczywiste. Co to znaczy, że jakaś matematyczna struktura reprezentuje zjawiska w przyrodzie? Jak abstrakcyjna matematyczna struktura może reprezentować coś realnego? Obiekty fizyczne są elementami realnego świata i różnią się od obiektów logicznych i matematycznych danych przez układ definicji i aksjomatów. Realiści zakładają jednak, że rzeczywistość jako taka jest strukturą, czyli zbiorem obiektów i relacji między nimi. Reprezentacja jednej struktury przez inną rozumiana jest w tym kontekście w sposób techniczny jako izomorfizm (lub czasami słabiej, jako homomorfizm) struktur.

Van Frassen twierdzi, że rozumienie reprezentacji jako izomorficznego odwzorowania miedzy strukturami rzeczywistymi i abstrakcyjnymi modelami jest zbyt uproszczone. W jakim sensie np. określone byty fizyczne są izomorficzne z pewnymi abstrakcyjnymi obiektami matematycznymi? Jak np. punkty w przestrzeni Minkowskiego odpowiadają zdarzeniom w rzeczywistej przestrzeni i czasie?63. Reichenbach uważał, że to, co łączy realne zjawiska i równania matematyczne, to odwzorowanie pomiędzy strukturą zjawisk a strukturą matematyczną. Dla przykładu przytaczał prawo Boyla PV=RT i przyjął, że zmiennym matematycznym można

$62 \mathrm{H}$. Reichenbach, The Theory of Relativity and A Priori Knowledge, Berkeley 1965, 37.

63 Por. B. van Frassen, Representation: The problem for Structuralism, dz. cyt., 544. 
przyporządkować wielkości fizyczne, takie jak ciśnienie, objętość i temperatura. Zakłada zatem, że istnieją takie wielkości fizyczne jak temperatura, które można przypisać ciałom gazowym bez odwoływania się do jakiejkolwiek teorii gazu, która tym pojęciom nadaje sens. Zakłada, że natura (rzeczywistość fizyczna) sama ma strukturę relacyjną, dokładnie określoną $\mathrm{w}$ taki sam sposób, jak struktura matematyczna. Matematyczny model reprezentuje rzeczywistość, jeśli jest obrazem lub kopią struktury tej rzeczywistości w sensie izomorficznego odwzorowania rzeczywistości ${ }^{4}$. Powraca więc pytanie, w jaki sposób rzeczywiste zjawiska mogą być izomorficzne $\mathrm{z}$ abstrakcyjną strukturą.

Proste wyobrażenie reprezentacji jako odwzorowania jest błędne. Jeśli mówimy o odwzorowaniu, to w grę wchodzą dwa określone zbiory: zbiór, który jest jego dziedziną i zbiór, który jest jego obrazem. Elementy obu struktur powinny być zdefiniowane w sposób niezależny od odwzorowania. Tymczasem w wypadku rzeczywistości brak jest takiego zdefiniowania elementów jej struktury, pierwotnego w stosunku do odwzorowania w struktury matematyczne. Czy gaz jest naturalną strukturą ciśnienia, objętości i temperatury, niepowiązaną $\mathrm{z}$ teorią gazu, która ujętym $\mathrm{w}$ matematycznym równaniu parametrom nadaje sens empiryczny? Pytanie, w jaki sposób określona struktura matematyczna może być użyta do reprezentowania określonych zjawisk, ma sens tylko w kontekście, w którym istnieje jakiś opis tych zjawisk, wyodrębniający reprezentowane obiekty i ich relacje. Możemy wyodrębnić w zjawiskach określone parametry i powiązać z nimi odpowiednie liczby, reprezentujące ich wartości, jeśli dysponujemy opisem zjawiska, w którym te parametry mają sens. Jeśli istnieje opis przemiany gazowej w kategoriach temperatury, ciśnienia i objętości, to możemy wtedy odwzorować je w określoną strukturę matematyczną, np. w tzw. model danych. Model może reprezentować

64 H. Reichenbach, The Theory of Relativity and A Priori Knowledge, dz. cyt., 37. 
rzeczywisty system tylko jako opisany w jakimś języku, w którym zostaną określone indywidua danego systemu i relacje między nimi.

Adekwatność teorii w odniesieniu do zjawisk polega na tym, że struktury, które reprezentują zjawiska w kategoriach odpowiednich parametrów, „pasują” (np. są izomorficzne) do modelu teoretycznego ${ }^{65}$. Jaki jest stosunek empirycznej adekwatności i prawdy teorii naukowej? Teoria jest empirycznie adekwatna, jeśli posiada model izomorficzny ze strukturą obserwowalnych zjawisk. Czy możemy sensownie twierdzić, że teoria jest również prawdziwa, że odzwierciedla nie tylko wszystkie obserwowalne zjawiska, ale i nieobserwowalne systemy i procesy występujące w przyrodzie? Modele teorii są bytami matematycznymi, więc jedyne, co posiadają, to struktura i to, co mogą reprezentować, to tylko struktura. Niemniej mogą reprezentować te struktury zjawisk poprawnie lub błędnie.

Jak zauważa van Frassen, matematyczne struktury teorii nie odzwierciedlają samych zjawisk, lecz jedynie matematyczną strukturę danych, będącą innym, kolejnym matematycznym modelem zjawisk. Nie zachodzi odwzorowanie pomiędzy strukturą rzeczywistości i strukturą matematyczną, lecz pomiędzy dwoma strukturami matematycznymi: matematyczną strukturą danych empirycznych (modelem danych) i matematyczną strukturą, będącą modelem teoretycznym. Model teoretyczny reprezentuje w bezpośredni sposób nie rzeczywistość, lecz model danych. Izomorfizm zachodzi pomiędzy modelem danych i modelem teorii, a nie rzeczywistością i modelem teorii. Pytanie o to, jak model teorii reprezentuje rzeczywistość, czyli jak model abstrakcyjny może reprezentować realne zjawiska, zostało teraz przesunięte na poziom odwzorowania rzeczywistości w modelu danych. Na jakiej podstawie można uznać, że model danych, będący również modelem abstrakcyjnym, reprezentuje zjawiska empiryczne? Czy pytanie: ,jak struktury danych reprezentują

65 B. van Frassen, Structure and Perspective: Philosophical Perplexity and Paradox w: Logic and Scientific Methods, Vol. 1, red. M.L. Dalla Chiara, Dordrecht 1997, 524. 
zjawiska?”, jest tego samego rodzaju, co pytanie: ,jak model teorii reprezentuje zjawiska?"66.

\section{MODELE DANYCH A REPREZENTACJA RZECZYWISTOŚCI W TEORIACH NAUKOWYCH}

Model danych nie jest zbiorem danych, uzyskanych bezpośrednio w wyniku obserwacji, lecz pewną jego poprawioną wersją, poddaną pewnym idealizującym zabiegom. Np. usuwa się wyniki uznane za błędne (co często oznacza wyniki odległe od średniej wartości). Dane przedstawia się $\mathrm{w}$ postaci uporządkowanej matematycznie, np. jako punkty wyznaczające krzywą o określonej matematycznie postaci. To modele danych, a nie surowe dane, mają udział w potwierdzaniu teorii. Nieuporządkowane surowe dane, nie poddane redukcji i nie zinterpretowane w postaci matematycznej zależności (np. liniowej, eksponencjalnej itp.), nie mogą być porównywane z matematycznym modelem teorii. Tworzenie modelu danych rodzi problemy metodologiczne i epistemologiczne, jakie są związane $\mathrm{z}$ wyborem punktów, które są usunięte ze zbioru pomiarów, jak też z wyborem krzywej, nadającej odpowiednią matematyczną strukturę zbiorowi danych, gdyż same dane nie wyznaczają jednoznacznie krzywej, lecz moga być dopasowane do wielu różnych krzywych ${ }^{67}$.

Zatem problem reprezentowania rzeczywistości w modelu danych otwiera wiele pytań tak metodologicznych, jak epistemologicznych. Już sama struktura modelu, związana zarówno $\mathrm{z}$ wyborem wyników uznawanych za poprawne, jak też z dopasowaniem krzywej, rodzi pytanie o prawdziwość lub co najmniej adekwatność reprezentacji zjawisk w modelu danych. Jak zauważa van Frassen, jeśli

66 B. van Frassen, Representation: The problem for Structuralism, dz. cyt., 544.

67 Bardziej dokładne omówienie modeli danych można znaleźć w: P. Suppes, Models of Data, w: Studies in the Methodology and Foundations of Science: Selected Papers from 1951 to 1969, red. P. Suppes, Dordrecht 1969, 24-35. 
reprezentowany system nie jest przedmiotem matematycznym, nie ma dobrze zdefiniowanych obiektów, które byłyby odwzorowywane w modelu, to jak można mówić o odwzorowaniu w sensie izomorfizmu lub homomorfizmu ${ }^{68}$.

Jeśli teorie reprezentują system rzeczywisty nie bezpośrednio, lecz za pośrednictwem modelu danych, który z kolei jest pewną wyselekcjonowaną i wygładzoną wersją zbioru danych (pomiarów), a więc strukturą matematyczną, to obrona stanowiska realistycznego musi wyjaśnić, jak model danych reprezentuje rzeczywistość. Model danych jest ważny nie sam w sobie, ale jako reprezentacja zjawisk. Adekwatność modelu danych dotyczy struktury rzeczywistych zjawisk opisywanych w kategoriach odpowiednich parametrów teorii. Obok struktury ważne są zatem parametry ją wyznaczające, a tym nadaje sens teoria.

Skoro struktura danych nie jest wolna od wyboru teorii, pojawia się pytanie, czy model danych reprezentuje rzeczywistość niezależną od teorii. Jak wskazuje van Frassen, nie ma niczego w modelu teorii, co determinowałoby określony model danych. Np. funkcja eksponencjalna może równie dobrze reprezentować wzrost populacji bakterii, jak rozpad izotopów promieniotwórczych w czasie. To, że dana funkcja reprezentuje np. wzrost danej populacji, nie jest zdeterminowane przez tę funkcję (model teorii), lecz przez użycie jej do reprezentowania wzrostu danej populacji. $Z$ drugiej strony w samym zjawisku bez odniesienia do jakiejkolwiek teorii nie ma niczego, co w sposób naturalny determinowałoby taki, a nie inny model danych, co narzucałoby strukturę modelu danych. Zależy ona od tego, w jakim aspekcie badamy zjawisko, jakie parametry uznamy za ważne dla jego istoty, co pominiemy w procesie abstrakcji, w jaki sposób reprezentujemy zjawisko, w jakim zakresie itp.

68 Por. B. van Frassen, Science as Representation: Flouting the Criteria, Philosophy of Science 71(2004)5, 794-804; S. French, N. da Costa, Theories, models and structures: thirty years on, Philosophy of Science 67(2000)4, 116-127. 
Frederick Suppe wskazuje, że abstrakcyjne struktury nie stają się teoriami naukowymi, dopóki nie zostaną wyposażone w fizyczną interpretację, czyli relację przyporządkowującą (mapującą) strukturę teorii i strukturę zjawiska. Taka interpretacja nie jest jednak relacją ekstensjonalną, lecz jest intensjonalna, zależna od teorii i modyfikowana wraz z rozwojem nauki ${ }^{69}$.

Pojawia się dodatkowy wymiar relacji pomiędzy rzeczywistością a formalizmem teorii, jeśli ma on być rozumiany jako reprezentacja rzeczywistości. Reprezentacja nie jest relacją dwuwymiarową - modelu i rzeczywistości lub modelu danych i modelu teoretycznego, lecz jest relacją co najmniej trójwymiarową. Struktura reprezentuje zjawiska, jeśli ktoś użył tej struktury do reprezentowania zjawisk w określonym aspekcie odzwierciedlonym w tej strukturze lub odczytał tę strukturę jako reprezentującą takie lub inne zjawisko. Użycie modelu, np. równania matematycznego, do reprezentowania danego zjawiska, np. użycie funkcji esponencjalnej do przedstawienia wzrostu populacji bakterii, jest niezbędne, aby funkcja była modelem tego zjawiska, choć może być to model nieadekwatny. Jednak samo dodanie warunku, że naukowiec użył dany model z intencją reprezentowania danego systemu też nie jest wystarczające, jeśli model nie odzwierciedla zjawiska $w$ wybranym aspekcie. W tym sensie izomorfizm struktur jest dobrym nośnikiem reprezentacji (sposobem reprezentowania), ale nie mówi, co jest reprezentowane przez model, czyli nie wyjaśnia reprezentacyjnej funkcji modelu.

Jak twierdzi van Frassen, teoria nie jest adekwatna do zjawisk, ale jest adekwatna do zjawisk jako reprezentowanych przez kogoś pod jakimś względem, czyli jeśli jest zgodna z modelem danych. Dla empiryzmu konstruktywnego, który rozwija van Frassen, nie ma różnicy, czy teoria reprezentuje model danych czy zjawisko, gdyż model danych jest utożsamiony ze zjawiskiem przedstawionym w języku,

69 Por. F. Suppe, The Semantic Conception of Theories and Scientific Realism, Chicago 1989, 422-423. 
w którym je opisujemy. Dla wyjaśnienia tej zależności porównuje teorię do mapy. Aby posłużyć się mapą (niezależnie od tego, że odwzorowuje ona jakiś teren w formie abstrakcyjnego modelu), należy odnieść ją do tego terenu, który ona reprezentuje, czyli opisać teren w kategoriach dróg, lasów, zabudowań itp. Dopiero do tak opisanych elementów terenu można odnieść abstrakcyjne znaki na mapie. Można też powiedzieć, że reprezentuje ona prawdziwie lub nie $e^{70}$. To odniesienie, jak określa van Frassen, nie jest semantyczne, nie należy do języka, ma charakter indeksowy, ale wymaga języka.

Jak utrzymuje empiryzm konstruktywny, teoria jest empirycznie adekwatna, jeśli posiada model izomorficzny z modelem danych, natomiast według realizmu strukturalnego teoria jest prawdziwa, jeśli posiada model izomorficzny ze strukturą obserwowalnych zjawisk. $\mathrm{Z}$ perspektywy realizmu adekwatność $\mathrm{z}$ modelem danych nie jest tym samym, co prawdziwość teorii. Model danych może być bowiem rozumiany jako reprezentacja rzeczywistości lub jako reprezentacja jedynie świata postulowanego przez teorię. Istnieje różnica pomiędzy pytaniem: czy model danych spełnia model teoretyczny? i pytaniem: czy model danych reprezentuje realne systemy i zjawiska? Trzeba więc ustalić, jakie warunki powinien spełniać model danych, aby spełnione były tezy realizmu naukowego, tzn. teza, że jest on poznawczym ujęciem rzeczywistości, niezależnej od naszego umysłu i założeń teoretycznych, oraz teza, że dostarcza on prawdziwej wiedzy o rzeczywistości, która jest następnie reprezentowana w teorii.

Model danych, jak zauważa van Frassen, nie może być oparty na izomorfizmie struktur, ponieważ jeśli reprezentowany system nie jest przedmiotem matematycznym i nie ma dobrze zdefiniowanych obiektów, które byłyby odwzorowywane w modelu, to nie można mówić o odwzorowaniu w sensie izomorfizmu lub homomorfizmu ${ }^{71}$.

70 B. van Frassen, Structure and perspective..., dz. cyt., 522.

71 Por. Tenże, Science as Representation: Flouting the Criteria, dz. cyt., 794-804; S. French, N. da Costa, Theories, models and structures: thirty years on, dz. cyt., 116-127. 
Struktury modelu danych odzwierciedlają własności zjawisk, jednak reprezentowany fragment rzeczywistości nie ma jednej przypisanej sobie struktury, lecz w zależności od opisu może przejawiać różne nieizomorficzne struktury. To, jakie indywidua i jakie relacje wyróżnimy, zależy (przynajmniej w części) od przyjętej aparatury pojęciowej. Modele danych, pełniące rolę reprezentacji, muszą zawierać elementy językowe (opisy) i niejęzykowe (struktury). Język jest niezbędny, aby połączyć strukturę modelu z rzeczywistością. Podobnie utrzymuje Teller, według którego model reprezentuje własności systemów realnych. System realny posiada własności, które są też częścią modelu. W tym ujęciu obiekty modelu są zbiorami własności. Systemy mają własności, które są częścią modelu ${ }^{72}$. Proponowane przez semirealizm wzbogacenie struktur abstrakcyjnych własnościami detekcyjnymi wydaje się w ten sposób ujmować reprezentowaną rzeczywistość. Jednak ujęcie to wydaje się dzielić wszystkie omówione trudności modelu danych.

Powyższe rozważania pokazują, że pojęcie reprezentacji, rozumianej jako izomorfizm struktur rzeczywistych i modelu teoretycznego, który miał uzasadniać zgodnie z realizmem strukturalnym realizm naukowy, jest za słabe, aby wyjaśnić związek rzeczywistego systemu i modelu danych. Aby móc przyjąć jaką̧s formę realizmu, należy obronić tezę, że systemy reprezentowane istnieją niezależnie od reprezentacji oraz wyjaśnić, jak są ujmowane w modelu. Konstruktywiści zakładają, że nie ma zjawiska niezależnego od jego reprezentacji, tzn. system reprezentowany jest dany przez jego model. Przedmiot reprezentowany jest sprowadzony do modelu danych. Model i to, co on reprezentuje, to $\mathrm{z}$ perspektywy realizmu dwa różne obiekty. Realizm potrzebuje koncepcji reprezentacji, w której zostanie wyjaśniony związek modelu danych i systemu rzeczywistego z zachowaniem ich rozróżnienia. Strukturalizm, jak zostało pokazane, jest zbyt wąskim ujęciem, aby w jego ramach wyjaśniony został problem

72 P. Teller, Twilight of the Perfect Model Model, Erkenntnis 55(2001)3, 399. 
reprezentacji rzeczywistości w modelu danych, a tym samym w teoriach naukowych.

\section{ZAKOŃCZENIE}

Podjęta analiza pokazuje, że realizm strukturalny dostarcza odpowiedzi na wyzwanie argumentu ze zmiany teorii w duchu realizmu naukowego, jednak odpowiedź ta generuje trudności, które wymagaja dalszych rozwiązań. Podstawowe trudności związane są z wyjaśnieniem, jak struktury matematyczne, które są modelami teorii, mogą reprezentować realne zjawiska. Łączą się one z pojęciem reprezentacji rzeczywistości w modelu teorii. Reprezentacja, zgodnie z założeniem realizmu strukturalnego, jest izomorficznym odwzorowaniem struktur. Model reprezentacji jako izomorficznego odwzorowania między strukturami rzeczywistymi i abstrakcyjnymi okazuje się zbyt uproszczony. Odwzorowanie realnych zjawisk w równania matematyczne, np. za pomocą mierzalnych parametrów, wymaga opisu tych zjawisk w jakimś języku teorii, nadającej tym parametrom sens. Analiza związku modelu teorii z realnym systemem pokazuje, że pomiędzy zjawiskami a modelem teorii pośredniczy model danych. Model teorii reprezentuje rzeczywistość za pośrednictwem modelu danych. Istotny dla realizmu problem realistycznego wyjaśnienia reprezentacji rzeczywistości w modelu teorii przesuwa się teraz na wyjaśnienia, jak rzeczywistość jest reprezentowana w matematycznym modelu danych. Realizm strukturalny wymaga zatem uzupełnienia o realistyczną interpretację modelu danych.

Model danych różni się od modelu teorii i nie jest wolny od języka teorii, gdyż język ten wyznacza parametry, odzwierciedlane w modelu, oraz nie jest wolny od decyzji badacza odnośnie do celu, aspektu, zakresu reprezentacji zjawiska, a tym samym wykracza poza ramy realizmu strukturalnego. Dalszym zadaniem dla realizmu strukturalnego jest opracowanie koncepcji reprezentacji zjawisk $\mathrm{w}$ modelu danych $\mathrm{z}$ zachowaniem odróżnienia modelu danych od 
realnego zjawiska. Semirealizm, choć odwołuje się do tzw. własności detekcyjnych realnych systemów, dzieli z realizmem strukturalnym jego trudności, dotyczące wyjaśnienia reprezentacyjnej roli modelu danych.

\section{BIBLIOGRAFIA}

Boyd R., On the Current Status of the Issue of Scientific Realism, Erkenntnis 19(1983)1, 45-90.

Chakravartty A., Semirealizm, Studies in History and Philosophy of Science 29(1998)3, 391-408.

Chakravartty A., The Semantic or Model Theoretic View of Theories and Scientific Realism, Synthese 127(2001)3, 325-345.

Da Costa N., French S., The Model-Theoretic Approach to the philosophy of Science, Philosophy of Science 57(1990)2, 248-265.

French S., Da Costa N., Theories, models and structures: thirty years on, Philosophy of Science 67(2000)4, 116-127.

Frigg R., Scientific Representation and the Semantic View of Theories, Theoria 21(2006)1, 49-65.

Giere R. Explaining Science: A Cognitive Approach, University of Chicago Press, Chicago 1988.

Giere R., How Models Are Used to Represent Reality, Philosophy of Science 71(2004)5, 742-52.

Grobler A., Prawda a względność, Wydawnictwo Aureus, Kraków 2000.

Howson C., Exhuming the No Miracles Argument, Analysis 73(2013)2, 205-211.

Kotowski M., O rozwoju realizmu naukowego jako selektywnego sceptycyzmu, Filozofia Nauki 22(2014)3, 105-123.

Kotowski M., Realizm zreformowany: Filozofia Iana Hackinga a spór o status poznawczy wiedzy naukowe, Oficyna Naukowa PFF, Wrocław 2016.

Laudan L., Obalenie realizmu konwergentnego, tłum. z ang. M. Kotowski, w: Spór o realizm naukowy. Mata antologia, red. M. Kotowski, Oficyna Naukowa PFF, Wrocław 2018, 29-66.

Lyons T.D., Scientific Realism and the Stratagema de Divide et Impera, The British Journal for the Philosophy of Science 57(2006)3, 537-560.

Poincaré H., Science and Hypothesis, The Water Scott Publishing, New York 1905.

Psillos S., Knowing the Structure of Nature, Palgrave Macmillan, New York 2009.

Psillos S., Scientific realism and metaphysics, Ratio (new series) 18(2005)4, 385-404. 
Psillos S., Scientific Realism: How Science Tracks Truth, Routledge, London 1999. Putnam H., What is Mathematical Truth? w: Tenże, Mathematics, Matter and Method, Collected Papers, Vol. 2, Cambridge University Press, Cambridge 1975, 60-78.

Reichenbach H., The Theory of Relativity and A Priori Knowledge, University of California Press, Berkeley1965.

Suppe F., The Semantic Conception of Theories and Scientific Realism, University of Illinois Press, Chicago 1989.

Suppes P., Models of Data, w: Studies in the Methodology and Foundations of Science: Selected Papers from 1951 to 1969, red. P. Suppes, Reidel, Dordrecht 1969, 24-35. Teller P., Twilight of the Perfect Model Model, Erkenntnis 55(2001)3, 393-415.

Van Frassen B., Representation: The problem for Structuralism, Philosophy of Science 73(2006)5, 536-547.

Van Frassen B., Science as Representation: Flouting the Criteria, Philosophy of Science 71(2004)5, 794-804.

Van Frassen B., Structure and Perspective: Philosophical Perplexity and Paradox w: Logic and Scientific Methods, Vol. 1, red. M.L. Dalla Chiara, Kluwer, Dordrecht 1997, 511-530.

Van Frassen B., The Scientific Image, Oxford University Press, Oxford 1980.

Worrall J., Miracles and Models: Why Reports of the Death of Structural Realism May Be Exaggerated, Royal Institute of Philosophy. Supplement 61(2007)10, 125-154. Worrall J., Realizm strukturalny. To co najlepsze z dwóch swiatów, tłum. $\mathrm{z}$ ang. M. Kotowski, w: Spór o realizm naukowy. Mata antologia, red. M. Kotowski, Oficyna Naukowa PFF, Wrocław 2018, 145-175.

\section{STRUCTURAL REALISM AND THE PROBLEM OF REPRESENTATION IN SCIENCE IN THE CONTEXT OF THE DISPUTE OVER SCIENTIFIC REALISM}

\footnotetext{
Abstract. The aim of this article is to present structural realism as a realistic position in the discussion around scientific realism - its selected advantages and weaknesses. Structural realism is a response to the challenge that the historical facts theory change in science pose to scientific realism. It refers to the semantic approach to scientific theories and the conceptual apparatus developed in this approach. According to structural realism, what is preserved from mature theories when a theory is changed are their mathematical formulations, which are abstract models of the theory. They are approximately true because they represent the structures of reality in a way that is free from the ontological interpretation imposed by the language of the theory. Structural realism and the semi-realism related to it, which extends the invariance of mature theories to the detection properties of physical
} 
objects, defend the theses of scientific realism in the matter of the approximate truth of scientific theories by realistically interpreting changes in scientific theories. However, they leave aside the problem of representing reality in scientific theories, which is essential for realism. Both of the above-mentioned positions, by referring to the model-theoretic approach to scientific theories assume that a representation is simply an isomorphism of the structure of the mathematical model of a theory and the structure of reality. Such understanding of a representation is too narrow: it does not take into account that the structure of phenomena is not clearly defined. In a theory, a real phenomenon is replaced by a data model, a mathematical structure that reflects the phenomena represented as relationships of the properties defined by the theory. A realistic interpretation of the data model is a necessary supplement to structural realism in order for it to satisfy the main thesis of realism that the reality which scientific theories describe is largely independent of theoretical commitments. This is the basis for defending the thesis about the approximate truth of the theory defended by structural realism. The aim of this paper is to motivate the need to extend structural realism and semi-realism with a richer and more adequate concept of representation. This article presents the basic elements of the contemporary discussion around scientific realism and the positions of structural realism and semi-realism as the reconciliation of scientific realism with the historical facts of theory change. Next, it highlights the consequences for structural realism resulting from the semantic (model theoretic) approach to scientific theories and the related notion of representation as an isomorphism of structures. The final section is devoted to arguing that in order to meet the postulates of scientific realism, structural realism and semi-realism should be supplemented with an explanation of the representation of reality in the data model in accordance with scientific realism.

Keywords: scientific realism; structural realism; semi-realism; representation in science; model of theory; data model; structure of scientific theory

Janina Buczkowska

Uniwersytet Kardynała Stefana Wyszyńskiego w Warszawie, Instytut Filozofii

(Cardinal Stefan Wyszyński University in Warsaw, Institute of Philosophy, Poland)

ORCID: https://orcid.org/0000-0001-5387-2310

janina.buczkowska@uksw.edu.pl

DOI: $10.21697 /$ spch.2020.56.4.08 